\title{
New contributions on flora and vegetation of northeastern Portugal ultramafic outcrops
}

\author{
Carlos Aguiar (*), Tiago Monteiro-Henriques (**) \& Daniel Sánchez-Mata (***)
}

\begin{abstract}
Aguiar, C., Monteiro-Henriques, T. \& Sánchez-Mata, D. New contributions on Flora and Vegetation of northeastern Portugal ultramafic outcrops. Lazaroa 34: 141-150 (2013).

In this work we present some syntaxonomic novelties on the vegetation of the referred ultramafic outcrops focused on three new associations: Jonopsidio abulensis-Sedetum maireani, Armerio daveaui-Agrostietum castellanae and Seseli peixotoani-Avenuletum lusitanicae; in addition, a new nomenclatural combination of an endemic taxon from the Morais massif (Armeria langei subsp. marizii) is proposed. We also clarify the phytocoenotic structure of the Portuguese vegetation series through a simple diagrammatic representation, which is then applied to one unique climatophilous vegetation series present in the ultramafic rocks of northeastern Portugal: Genisto hystricis-Querco rotundifoliae Sigmetum.
\end{abstract}

Keywords: Ultramafic vegetation, ultramafic flora, ultramafic vegetation series, Armeria langei subsp. marizii, Portugal.

Resumen: Aguiar, C., Monteiro-Henriques, T. \& Sánchez-Mata, D. Nuevas contribuciones a la Flora y Vegetación de los macizos ultramáficos del noreste de Portugal. Lazaroa 34: 141-150 (2013).

Se presentan algunas novedades sintaxonómicas referidas a la vegetación ultramáfica del noreste de Portugal proponiéndose tres nuevas asociaciones: Jonopsidio abulensis-Sedetum maireani, Armerio daveaui-Agrostietum castellanae y Seseli peixotoani-Avenuletum lusitanicae; además se propone una nueva combinación nomenclatural sobre un taxon endémico del macizo de Morais (Armeria langei subsp. marizii). Se clarifica, además, la estructura fitocenótica de la única serie de vegetación climatófila reconocida en las áreas ultramáficas del noreste de Portugal mediante una representación diagramática: Genisto hystricis-Querco rotundifoliae sigmetum.

Palabras clave: Vegetación ultramáfica, flora ultramáfica, serie de vegetación ultramáfica, Armeria langei subsp. marizii, Portugal.

\section{INTRODUCTION}

The presence of allochthonous ultramafic rocks is one of the most original characteristics of the northeastern Portugal geology (IGLESIAS \& al., 1983). These ultramafic rocks are spread throughout two large mafic and ultramafic massifs: Bragança and Morais (Figure 1). The altitude of the northern Bragança Massif varies between 600$1060 \mathrm{~m}$ asl; following the latest version of the Rivas-Martínez's Worldwide Bioclimatic Classification (RIVAS-MARTINEZ \& al., 2011), all the territory is included in the lower humid to upper humid supramediterranean bioclimatic belt. The
Morais Massif shows an upper subhumid to lower humid ombrothermic character, with a meso - to supramediterranean thermotype range. Its altitude ranges between 300 and $900 \mathrm{~m}$ asl (MONTEIROHenRiques \& Aguiar, 2010) (Figure 1).

The mineralogy and the chemical composition of ultramafic rocks are rather unusual and have a strong impact in soil genesis, plant evolution and vegetation assembling. Besides their meaning in the point of view of geodiversity, ultramafic rocks have an enormous social and scientific importance by their pedodiversity and as plant biodiversity refuges (SEQueIra \& al., 2010 García-BARRIUSO \& al., 2012).

\footnotetext{
*CIMO-Centro de Investigação de Montanha. Instituto Politécnico de Bragança. Apartado 1172, 5301-855 Bragança, Portugal. E-mail: cfaguiar@ipb.pt

**Centro de Botânica Aplicada à Agricultura. Instituto Superior de Agronomia. Universidade Técnica de Lisboa. Tapada da Ajuda, 1349-017 Lisboa, Portugal. E-mail: tmh@isa.utl.pt

***Department of Plant Biology II. Faculty of Pharmacy. Complutense University. E-28040 Madrid, Spain. E-mail: dsmata@ucm.es
} 


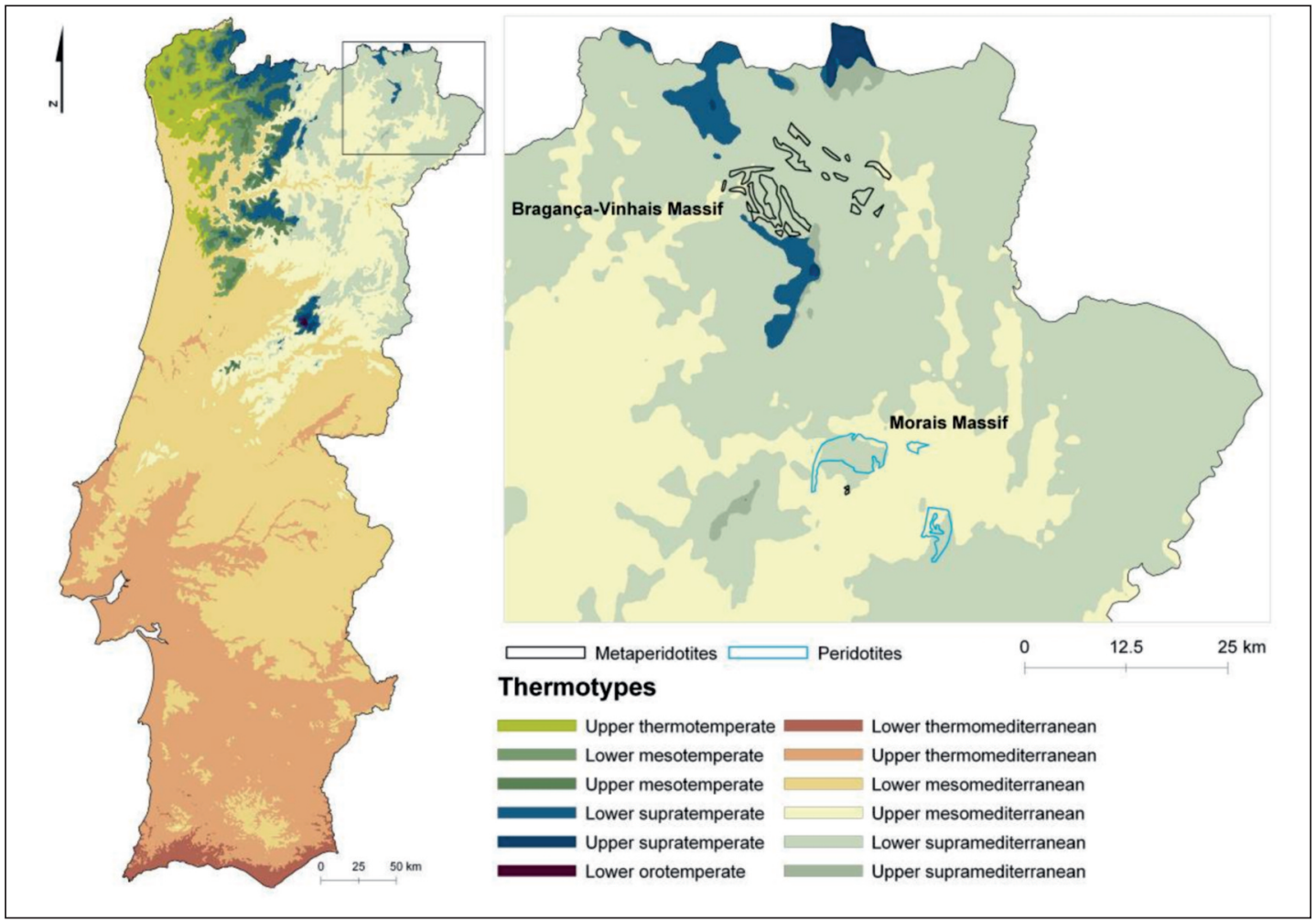

Figure 1. - Map of thermotypes of mainland Portugal according to the Rivas Martínez's Worldwide Bioclimatic Classification proposals (RIVAS-MARTíNEZ \& al., 2011), with particular focus on the Morais-Bragança area. Metaperidotites and peridotites from the Carta Geológica de Portugal 1/500000.

The main adverse factors conditioning plant life in ultramafic (serpentine) soils - the serpentine effect (KRUCKBERG, 1992) - are probably the high $\mathrm{Mg} / \mathrm{Ca}$ quotient (two divalent cations with an antagonist effect), the very high $\mathrm{Ni}$, and low N, P, K and Ca available (KRUCKBERG, 1986; BRADY \& al., 2005). These extreme ecological conditions impose a strong selective effect on the flora, which results in a widespread ecotypic differentiation among generalist plant species and in a high diversity of endemic species and biogeographical disjunctions, some of them with a relict character (KRUCKBERG, 1986).

Adding to the unfavorable soil conditions, often toxic, the Mediterranean climate of the referred Portuguese outcrops causes an additional hardship for the present flora: the shortage of rainfall in the months when the temperature reaches the highest annual values, which reduces the water availability for plants and causes increased salt concentration from the weathering of the rock. This combination of factors is recurrent in the Mediterranean biogeographical region sensu RIVAS-MARTínEZ (2004), where, due to its complex geology, there are several belts of ophiolitic rocks placed in allochthonous position by thrust faults, representing ancient distension basins (CAVAZZA \& al., 2004). From a biogeographic viewpoint, these ultrabasic complexes constitute a genuine system of islands with unique characteristics and recurring in the continental matrix throughout the Mediterranean basin, from Portugal to Turkey. Thus, areas next to ultrabasic outcrops tend to share a larger number of taxa, as would be expected according to the Theory of Island Biogeography (MAC ARTHUR \& WiLson, 1967). There are even some genera and species whose optimum appears to be strongly related to the presence of mafic and ultramafic rocks, spreading over the whole Mediterranean region, as it is the case of some perennial species of the genus 
Alyssum, or even the relict Notholaena marantae. For the genus Alyssum affinities between Iberian, Italic, Balkan and North African populations are now clearly recognized. It is noteworthy that the lowering of the sea level during glacial periods and in particular the strong lowering produced during the Messinian crisis, where the level of the Mediterranean Sea fell $1.5 \mathrm{~km}$ (CLAUZON \& al., 1996) may have contributed to a greater exchange of genetic material between the current system of islands, as ultramatic sediments may have been exposed (EMELYANOvA \& al., 2005) or ophiolite complexes which are presently submerged (EuROGeoSurveys, The Geological Surveys of Europe, 2010).

The toxicity of substrate, distance to other ultramatic massifs (isolation degree), as well as their size and the complex paleobiogeography of the Mediterranean region have determined that we can now find in the northeastern Portugal ultramafic massifs some endemic taxa and other rare plants (Table 1).

In serpentine soils, serpentinofuges are eliminated or their populations depressed by soil pro-

\section{Table 1}

Endemic taxa and other rare plants of the ultramafic outcrops of northeastern Portugal (Trás-os-Montes) (AgUIAR \& al., 2011a). IUCN categories of threat: Extinct, EX; Critically Endangered, CR; Endangered, EN; Vulnerable, VU; Near Threatened, NT: Least Concern, LC; Data deficient, DD.

\begin{tabular}{|c|c|c|c|}
\hline & $\begin{array}{l}\text { Bragança } \\
\text { massif }\end{array}$ & $\begin{array}{r}\text { Morais } \\
\text { massif }\end{array}$ & $\begin{array}{l}\text { IUCN categories of } \\
\text { threat (national } \\
\text { scale, IUCN, 2001) }\end{array}$ \\
\hline \multicolumn{4}{|l|}{ Portuguese endemic serpentinophytes } \\
\hline $\begin{array}{l}\text { Arenaria querioides Pourr. ex Willk. subsp. fontqueri (P. Silva) } \\
\text { Rocha Afonso }\end{array}$ & $\mathrm{x}$ & $\mathrm{x}$ & NT \\
\hline Armeria eriophylla Willk. & $\mathrm{x}$ & - & NT \\
\hline $\begin{array}{l}\text { Armeria langei Boiss. subsp. marizii (Daveau) C. Aguiar, } \\
\text { Sánchez-Mata \& Monteiro-Henriques comb. et stat. nov. }\end{array}$ & - & $\mathrm{x}$ & NT \\
\hline Avenula lusitanica (Romero Zarco) Holub & $\mathrm{x}$ & $\mathrm{x}$ & VU \\
\hline Festuca brigantina (Markgr.-Dann.) Markgr.-Dann. & $\mathrm{x}$ & - & EN \\
\hline \multicolumn{4}{|l|}{ Obligate serpentinophytes endemic to Galician and northeastern } \\
\hline Alyssum serpyllifolium Desf. subsp. lusitanicum Dudley \& P. Silva & $\mathrm{x}$ & $\mathrm{x}$ & $\mathrm{LC}$ \\
\hline \multicolumn{4}{|l|}{ Obligate serpentinophytes endemic of Iberian ultramafic rocks } \\
\hline Asplenium adiantum-nigrum L. subsp. corunnense (Christ) Rivas-Martín & ínez x & $\mathrm{x}$ & NT \\
\hline \multicolumn{4}{|l|}{$\begin{array}{l}\text { Other Iberian endemisms and other species, which in Portugal } \\
\text { occur exclusively on the northeastern ultramafic outcrops }\end{array}$} \\
\hline Antirrhinum rothmaleri (P. Silva) Amich \& al. & $\mathrm{x}$ & $\mathrm{x}$ & $\mathrm{CR}$ \\
\hline Anthyllis sampaioana Rothm. & $\mathrm{x}$ & - & VU \\
\hline Armeria langei Boiss. subsp. daveaui (Cout.) P. Silva & $\mathrm{x}$ & $\mathrm{x}$ & NT \\
\hline Astragalus incanus L. subsp. nummularioides (Desf.) Maire & $\mathrm{x}$ & - & VU \\
\hline Bromus squarrosus L. (Poaceae) & $\mathrm{x}$ & - & EN \\
\hline Dianthus laricifolius Boiss. \& Reut. subsp. marizii (Samp.) Franco & $\mathrm{x}$ & $\mathrm{x}$ & $\mathrm{LC}$ \\
\hline Elymus hispidus (Opiz) Melderis subsp. barbulatus (Schur) Melderis & $\mathrm{x}$ & - & DD \\
\hline Gagea pratensis (Pers.) Dumort. & $\mathrm{x}$ & - & $\mathrm{EN}$ \\
\hline Jasonia tuberosa (L.) DC. & $\mathrm{x}$ & - & $\mathrm{EN}$ \\
\hline Notholaena marantae (L.) Desv. subsp. marantae & $\mathrm{x}$ & $\mathrm{x}$ & VU \\
\hline Reseda virgata Boiss. \& Reut. & $\mathrm{x}$ & $\mathrm{x}$ & $\mathrm{LC}$ \\
\hline Santolina semidentata Hoffmanns. \& Link. & $\mathrm{x}$ & $\mathrm{x}$ & $\mathrm{LC}$ \\
\hline Saxifraga dichotoma Willd. & $\mathrm{x}$ & - & $\mathrm{EN}$ \\
\hline Seseli montanum L. subsp. peixotoanum (Samp.) M. Laínz & $\mathrm{x}$ & $\mathrm{x}$ & $\mathrm{LC}$ \\
\hline Silene legionensis Lag. & $\mathrm{x}$ & - & VU \\
\hline Ventenata dubia (Leers) Cosson & $\mathrm{X}$ & - & DD \\
\hline
\end{tabular}


prieties, while plant populations adapted to serpentines -the serpentinophytes- have lower competitive abilities in acid and basic rocks (KRUCKBERG, 1986; BRADY \& al., 2005). If the ultramafic flora is original, also are their socializations, i.e. vegetation.

The originality of the serpentine flora of northeastern Portugal probably was firstly recognized by W. Rothmaler and A.R. Pinto Silva when these two remarkable botanists visited the region in June of 1939 (Aguiar, 2002). Pinto da Silva dedicated a large part of his professional life to northeastern ultramafic flora and vegetation that culminated in his dissertation of 1970 (PINTO DA SILVA, 1970). Since then other botanists and vegetation scientists explored the region with important contributions gathered by AGUIAR (2002).

The invaluable commented checklist of the vascular flora of the ultramafic rocks of northeastern Portugal of PINTO DA SILVA (1970) has been recently reviewed by Aguiar and Monteiro-Henriques (ined., however see AGUIAR \& al., 2011a, for a prodromus). These authors' accept 569 taxa, $29 \%$ of which (165 taxa) are new additions to the original catalogue of PINTO DA SILVA (1970). Following the same trend in this paper we make a reappraisal of the vegetation (climatophilous sigmeta, permasigmeta, ephemerosigmeta and nonseral nitrophilous vegetation) of the ultramafic outcrops of northeastern Portugal.

We follow for taxonomic nomenclature basically the mentioned prodromus (AgUiAR \& al., 2011a) and for syntaxonomic the compilation of AgUiAR \& al., 2011b).

\section{MATERIAL AND METHODS}

Due to its complexity, the vegetation phenomenon is not understandable without a consistent conceptual framework. In vegetation science different objectives require different methods (KENT \& CoKer, 1992). Classical phytosociology -the continental European vegetation school of $\mathrm{Zu}$ rich-Montpellier- enhanced with the dynamicalcatenal approach developed by S. Rivas-Martínez (RIVAS-MARTínEZ, 2005), adopted in this paper, offer a consistent conceptual and methodological framework to explore the vegetation with a multipurpose output.

Vegetation series is one of the most useful but also critical concepts in dynamic-catenal phytosociology because a main question usually remains to be answered: what is a seral stage in a vegetation series? A vegetation series is a set of plant communities composed by a climax association - usually a forest in Mediterranean and Temperate macrobioclimates - and its substitution stages (RIVASMARTíneZ, 2005). Vegetation series occupies homogenous biotopes and its components -seral stages- are connected through successional processes. So semi-nitrophilous vegetation, plant communities' dependent of microtopographic features (e.g. temporary Mediterranean ponds vegetation) and functionally dependent communities (e.g. scionitrophilous forest vegetation and epiphytic vegetation) are not included in vegetation series descriptions. Successional mosaics with different phytocoenotic composition and structure are largely governed by stress (inc. nutritional stress), disturbance patterns, and diaspore availability.

Defined in this way Mediterranean vegetation series can be quite complex, in general substantially more than its Eurosiberian counterparts (Figure 2). The number of vegetation stages in the Portuguese Mediterranean vegetation series generally depends on the biogeographic and bioclimatic contexts (AguiAR \& al., 2005; PinTo-GOMES \& al., 2011; RiBEIRO \& al., 2012). Some of its seral stages have more than one plant community. For example, the mesotrophic perennial grasslands communities are usually distinct in landscapes with a forest or with a low scrub community matrix. The same phenomenon happens with tall shrublands structured by Cytisus and Genista species.

\section{RESULTS}

\section{CLIMATOPHILOUS VEGETATION SERIES (SIGMETA)}

There is one unique climatophilous vegetation series in the ultramafic rocks of northeastern Portugal-Genisto hystricis-Querco rotundifoliae sigmetum- lead by forests of Quercus rotundifolia (Genisto-Quercetum rotundifoliae) (AGUIAR \& 


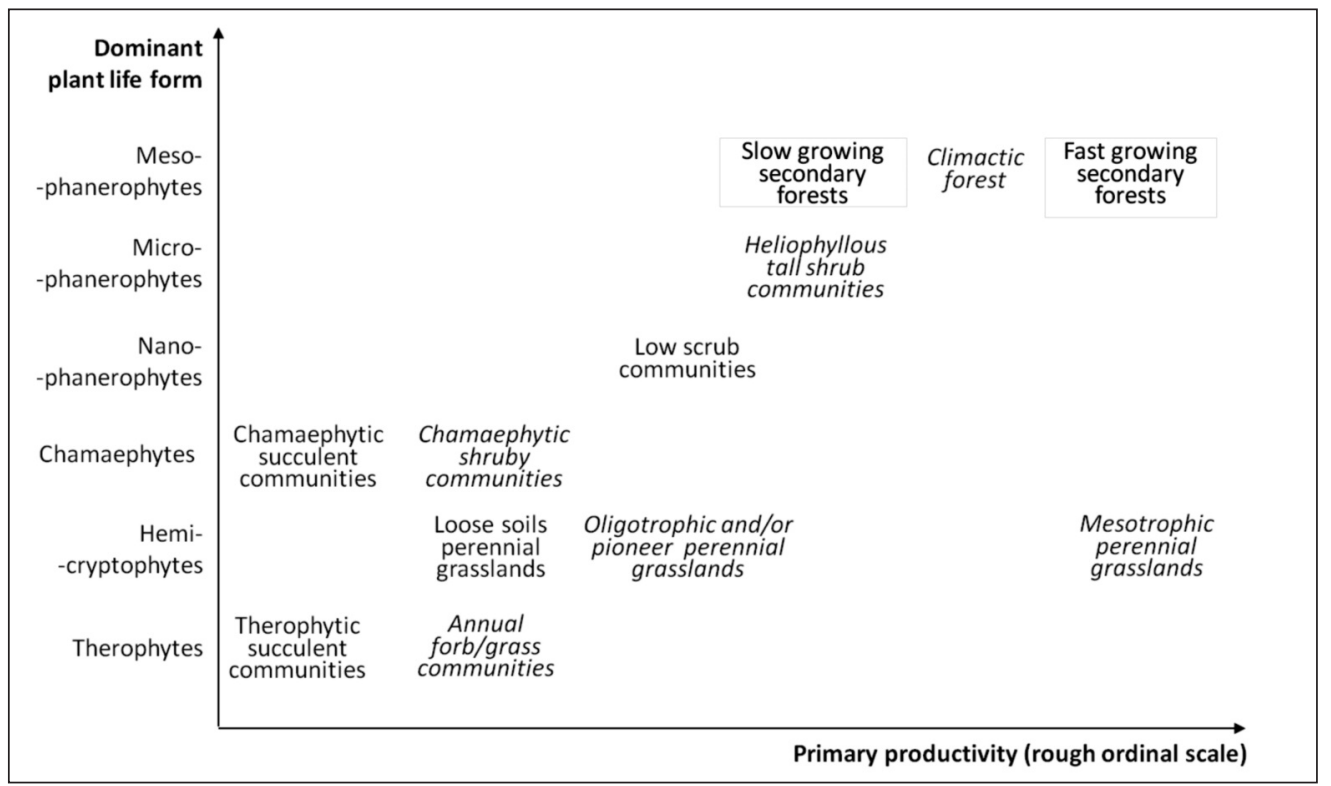

Figure 2.- Diagrammatic representation of the Portuguese vegetation series phytocoenotic structure. In italics: seral stages present in the climatophilous vegetation series of the ultramafic rocks of northeastern Portugal.

al., 2011b). The holm oak (Quercus rotundifolia) is the only Quercus species that withstands harsh serpentine effects. Substratum toxicity has a depressive effect on tree cover, height and productivity, as well as in Quercus rotundifolia forest resilience and resistance to disturbance. Consequently, heliophilous shrubs like Cistus ladanifer and Genista hystrix reach a high cover naturally in these forests and increase their proneness to wildfires. The low forest resilience, and the severity and short recurrence cycles of wildfires and herbivory disturbances, through a complex causeeffect chain, increase soil erosion susceptibility and soil toxicity, and slow down pedogenesis. Consequently, ultramafic cover vegetation and landscapes are composed of diversified successional vegetation mosaics (Figure 3 ).

In fact besides the unfavourable chemical soil proprieties, the flora and vegetation is also controlled by other environmental conditions like the dominance of thin soils, high soil temperatures and severe summer water shortage (SEQUEIRA \& PINTO DA SILVA, 1992; KRUCKBERG, 2002). The dominance of thin soils in the ultramafic is also due to the dominance of dissolution processes in rock chemical weathering (SEQUEIRA \& PINTO DA SILVA, 1992).
The most conspicuous seral stage of the ultramafic $Q$. rotundifolia forests is a shrub formation of Cistus ladanifer (Cisto ladaniferi-Genistetum hystricis). This heliophilous, aromatic and highly inflammable vegetation is poor in shrub species. In addition to $C$. ladanifer (Cistaceae) there are common Helichrysum stoechas (Asteraceae) and a few Lamiaceae like Lavandula pedunculata and Thymus mastichina that have also a medicinal use (GonZALÉz \& al., 2012). Deeper soils derived from ultramafic rocks, chiefly in concave physiographies in the midst of forest-dominated seral mosaics, under low disturbance regimes, are more suitable to tall shrub communities composed of nanophanerophytes of Genisteae tribe (family Fabaceae, e.g. Cytisus scoparius and C.multiflorus), of the Genisto hystricis-Cytisetum multiflori community (AGUIAR \& al., 2011b; GAVILÁN \& al., 2011).

It is a common characteristic of many serpentine areas around the world, to find large areas of rocky soil surfaces stripped of large biomass vegetation (KRUCKBERG, 1992). In northeastern Portugal these soils -leptosols- harbour two important endemics-rich vegetation types:

i) the pioneer tall perennial grasslands of the Seseli-Avenuletum lusitanicae ass. nova hoc loco 


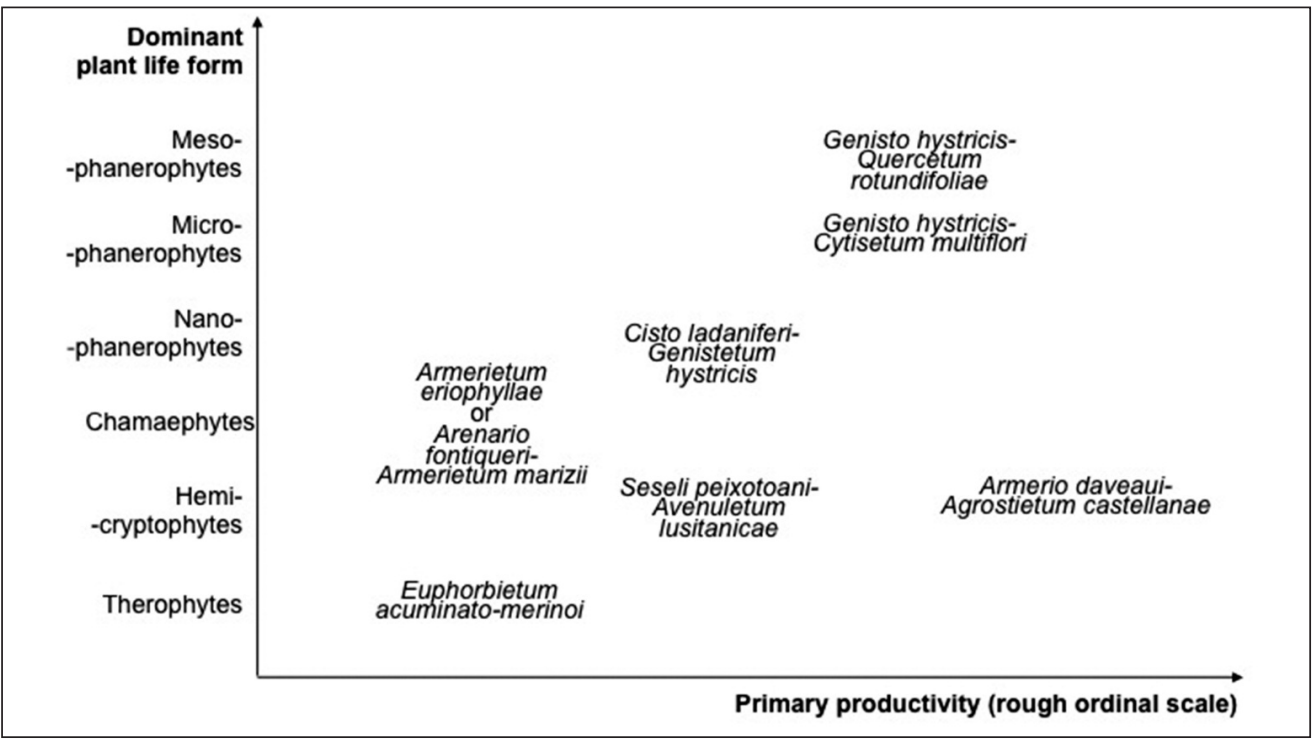

Figure 3. - Diagrammatic representation of the Genisto hystricis-Querco rotundifoliae Sigmetum, the climatophilous vegetation series of the ultramafic rocks of northeastern Portugal.

(Table 2, holotypus relevé no. 4), which inhabits heavily fractured and fragmented rock outcrops with a gentle slope, establishing complex mosaics with Armerion eriophyllae alliance communities, perennial grasslands of Agrostion castellanae alliance and annual grasslands of Brachypodion distachyi alliance, and

ii) the chamaephytic shrubby communities of the Armerietum eriophyllae in the Bragança ultramafic outcrops, or of the Arenario fontqueri-Armerietum marizii in the Morais massif (AGUIAR \& al., 1998).

An immediate conclusion of the fact that endemic-rich associations are occupying incipient soils is that successional progression, achieved through fire and herbivory suppression, can endanger these endemic plant populations. Chamaephytic shrubby communities of the Armerion eriophyllae have a low plant cover and are composed of prostrate perennial plants adapted to colonize small soil pockets in near horizontal, thin, rocky soils. These plants usually have a strong root system, capable of resisting the effects of sheet erosion. The chamaephytic shrubby communities coexist with highly diverse annual oligotrophic forb/grass communities like the Euphorbietum acuminato-merinoi. The dominant plants of tall pioneer perennial grasslands (Seseli-Avenuletum lusitanicae)-e.g. Koeleria crassipes and the en- demic Avenula lusitanica- display a phalanx strategy in colonial growth (LovetT Doust, 1981). The tightly packed colonial ramets spread slowly from putative seed growths, conquering space and gathering soil around them brought from above by rainwater superficial flow. With time, these small fertility islands coalesce and appear to have a facilitating effect on the species of other successional stages (e.g. mesotrophic perennial grasslands of the Agrostion castellanae alliance). This slow (secular?) course leads to the exclusion of chamaephytic shrubby community species, unless herbivore, fire or landslide disturbance resets the process.

Mesotrophic perennial grassland species are much more productive and palatable to mammal herbivores than pioneer communities' characteristic plants. Frequently occurring in forest clearings, the Armerio daveaui-Agrostietum castellanae ass. nova hoc loco consists in a supramediterranean, meso-xerophilous, mesotrophic perennial grassland of Armeria langei subsp. daveaui, Agrostis castellana and Centaurea langei, endemic of the ultramafic rock outcrops of northeastern Portugal. Particularly frequent in holm oak forest clearings (Genisto-Quercetum rotundifoliae) and rock platforms covered with a thick layer of soil, in the Bragança-Vinhais massif. 
Table 2

Seseli peixotoani-Avenuletum lusitanicae ass. nova

(Potentillo montanae-Brachypodienion rupestris, Potentillo montanae-Brachypodion rupestris, Brometalia erecti, Festuco-Brometea)

\begin{tabular}{lccccccc}
\hline Altitude (m asl) & 681 & 680 & 679 & 683 & 678 & 681 & 699 \\
Exposure & $\mathrm{N}$ & - & - & $\mathrm{N}$ & $\mathrm{N}$ & $\mathrm{N}$ & $\mathrm{NE}$ \\
Area $\left(\mathrm{m}^{2}\right)$ & 10 & 16 & 10 & 20 & 25 & 15 & 20 \\
N. species & 10 & 8 & 12 & 13 & 14 & 14 & 17 \\
Relevé N. & 1 & 2 & 3 & 4 & 5 & 6 & 7 \\
\hline
\end{tabular}

Characteristics

Avenula lusitanica

Seseli peixotoanum

Koeleria crassipes

Allium paniculatum

Filipendula vulgaris

Tulipa australis

Reseda virgata

Phleum bertolonii

Asperula scabra

Companions

Agrostis castellana

Centaurea langei

Ashodelus serotinus

Dactylis hispanica

Allium sardoum

Genista hystrix

Dianthus marizii

Thapsia minor

Alyssum lusitanicum

Allium sphaerocephalon

Arenaria fontqueri

Santolina semidentata

Plantago holosteum

\begin{tabular}{|c|c|c|c|c|c|c|}
\hline 3 & 3 & 2 & 4 & 3 & 4 & 3 \\
\hline 1 & 2 & 1 & 1 & 1 & 1 & 1 \\
\hline 1 & + & 1 & 1 & 1 & 1 & 2 \\
\hline . & . & 1 & + & + & . & . \\
\hline 1 & + & . & . & . & . & . \\
\hline+ & . & . & . & . & . & + \\
\hline$\cdot$ & . & 1 & . & . & 1 & . \\
\hline . & . & . & + & + & . & . \\
\hline . & . & . & . & + & 1 & . \\
\hline 3 & 3 & 3 & 3 & 3 & 2 & 3 \\
\hline 2 & 1 & 2 & 1 & 1 & 1 & + \\
\hline 2 & 1 & 1 & 2 & 1 & . & . \\
\hline 2 & 1 & 1 & . & 1 & . & + \\
\hline${ }^{\circ}$ & . & + & 1 & 1 & + & 1 \\
\hline$\cdot$ & . & . & 2 & 1 & 1 & + \\
\hline . & . & . & + & 1 & + & 1 \\
\hline 1 & 1 & + & . & . & . & . \\
\hline . & . & . & 1 & . & + & + \\
\hline . & . & 1 & . & 1 & . & . \\
\hline . & . & . & + & . & . & + \\
\hline . & . & . & . & 1 & 1 & . \\
\hline . & . & . & . & . & 1 & 2 \\
\hline
\end{tabular}

Other species: Helichrysum stoechas 1 in 6; Anthoxanthum odoratum, Centaurium majus, Cistus ladanifer and Cistus salviifolius + in 7 .

Localities: 1, 3, and 4: Vinhas, Monte de Morais, between Limãos and Sobreda (Macedo de Cavaleiros); 2, 5, and 6: Vinhas, Monte de Morais, between Castro Roupal and Sobreda (Macedo de Cavaleiros); 7; Morais, Monte de Morais, Sobreda (Macedo de Cavaleiros). Holotypus ass. rel. 4.

The holotypus of this newly proposed association is the following: Bragança: Carrazedo, ultramafic rocks, $640 \mathrm{~m}, 9 \mathrm{~m}^{2}$. Characteristic species: 5 Agrostis castellana, 2 Armeria langei subsp. daveaui, 1 Centaurea langei, + Dactylis hispanica, + Allium sphaerocephalon. Companion species: 1 Seseli montanum subsp. peixotoanum, + Alyssum serpyllifolium subsp. lusitanicum.

\section{TEMPORARY WET SOILS EPHEMEROSIGMETA}

In wet years, in the middle of spring, the small depressionary areas between the endemic-rich chamaephytic communities are filled with the lilac flowers of the succulent leaved Sedum maireanum (Crassulaceae). This species is generally accompanied by other annuals adapted to temporarily wet soils, like Spergularia segetalis (Caryophyllaceae), several species of annual Juncus (Juncaceae) and Molineriella laevis (Poaceae). The new association proposed here, Jonopsidium abulensis-sedetum maireani ass. nova hoc loco (Table 3, holotypus relevé no. 5). It occupies, supramediterranean, humid bioclimate areas and presents a unusual muscicolous habit. Being an ephemeral community with a precise vegetation dynamic, it 
Table 3

Jonopsidio abulensis-Sedetum maireani ass. nova hoc loco

(Cicendion, Isoetalia, Isoeto-Nanojuncetea)

\begin{tabular}{lcccccccccc}
\hline Altitude $(1=10 \mathrm{~m}$ asl $)$ & 91 & 84 & 87 & 90 & 87 & 90 & 90 & 88 & 105 & 90 \\
Area $\left(\mathrm{m}^{2}\right)$ & 2 & 4 & 4 & 4 & 4 & 2 & 2 & 2 & 4 & 1 \\
N. species & 7 & 12 & 10 & 12 & 13 & 10 & 7 & 10 & 10 & 5 \\
Relevé N. & 1 & 2 & 3 & 4 & 5 & 6 & 7 & 8 & 9 & 10 \\
\hline
\end{tabular}

Characteristics

Sedum maireanum

Spergularia segetalis

Juncus capitatus

Molineriella laevis

Jonopsidium abulense

Companions

Rumex gallicus

Asterolinon linum-stellatum

Moenchia erecta

Teesdalia coronopifolia

Arenaria querioides

Leontodon longirostris

Cerastium diffusum

Logfia minima

Herniaria scabrida

Linaria amethystea

Mibora minima

Trifolium arvense

Other species: Ranunculus paludosus and Scleranthus polycarpos + in 1; Tuberaria guttata 2, Galium parisiense + in 2; Spergularia purpurea + in 3; Spergularia morisonii + in 4; Plantago major 3, Carex divisa 1 in 8; Plantago radicata 2, Crassula tillaea, Euphorbia merinoi and Sagina apetala 1 in 9.

Localities: 1: Alimonde (Bragança); 2: Vilarinho da Cova de Lua (Bragança); 3 and 5: Espinhosela, Sardoal (Bragança); 4, 6, 7, and 10: Oleiros, Serro (Bragança); 8: Ousilhão (Vinhais); 9: Nogueira, estradão das Corriças (Bragança). Holotypus ass. rel. 5.

fits the recent concept of ephemerosigmetum proposed by Monteiro-Henriques (2010). This curious plant community can also be occasionally observed in holm oak (Q. rotundifolia) clearings, after the disturbance of the bryophyte covering by wild boars: an interesting ecological interaction between wild mammals and vascular plants.

\section{FLORISTIC APPENDIX}

Armeria langei Boiss. subsp. marizii (Daveau) C. Aguiar, Sánchez-Mata \& Monteiro-Henriques comb. et stat. nov. [Basionyme: Armeria eriophylla var. marizii Daveau in Bol. Soc. Brot. 6: 174. 1889].

\section{SYNTAXONOMIC SCHEME}

QueRCETEA ILICIS Br.-Bl. ex A. \& O. Bolòs 1950

Quercetalia ilicis Br.-Bl. ex Molinier 1934 em. Rivas-Martínez 1975

Quercion broteroi Br.-B1., P. Silva \& Rozeira 1956 corr. V. Fuente 1986 em. Rivas-Martínez 1975

Paeonio broteroi-Quercenion rotundifoliae Rivas-Martínez in Rivas-Martínez, Costa \& Izco 1986 Genisto hystricis-Quercetum rotundifoliae P. Silva 1975 
Genistion polygalaephyllae Rivas-Martínez, T. E. Díaz, F. Prieto, Loidi \& Penas 1984

Genisto hystricis-Cytisetum multiflori Rivas-Martínez, T. E. Díaz, F. Prieto, Loidi \& Penas 1984

Ulici europaei-Cytision striati Rivas-Martínez, Báscones, T.E. Díaz, Fernández-González \& Loidi 1991 Lavandulo sampaianae-Cytisetum multiflori Br.-B1., P. Silva \& Rozeira 1956

Cisto-LAVANDUletea Br.-Bl. in Br.-Bl., Molinier \& Wagner 1940

Lavanduletalia stoechadis Br.-Bl. in Br.-Bl., Molinier \& Wagner 1940 em. Rivas- Martínez 1968

Cistion laurifolii Rivas Goday 1956

Cisto ladaniferi-Genistetum hystricis P. Silva 1970

STIPo GIGANTEAE-AGRostietea CASTELlanaE Rivas-Martínez, Fernández-González \& Loidi 1999 Agrostietalia castellanae Rivas Goday in Rivas-Martínez, Costa, Castroviejo \& E. Valdés 1980 Agrostion castellanae Rivas Goday 1958 corr. Rivas Goday \& Rivas-Martínez 1963

Armerio daveaui-Agrostietum castellanae Aguiar, Monteiro-Henriques \& Sánchez-Mata ass. nova

FestuCo-BRometeA Br.-B1. \& Tüxen ex Br.-B1. 1949

Brometalia erecti Br.-Bl. 1936

Potentillo montanae-Brachypodion rupestris Br.-Bl. 1967 corr. Rivas-Martínez, T.E. Díaz, Fernández-González, Izco, Loidi, Lousã \& Penas 2002

Potentillo montanae-Brachypodienion rupestris J. Guitán, Izco \& Amigo 1989

Seseli peixotoani-Avenuletum lusitanicae Aguiar, Monteiro-Henriques \& Sánchez-Mata ass. nova

FESTUCETEA INDIGESTAE Rivas Goday \& Rivas-Martínez 1971

Jasiono sessiliflorae-Koelerietalia crassipedis Rivas-Martínez \& Cantó 1987

Armerion eriophyllae P. Silva 1970

Armerietum eriophyllae Pinto da Silva 1965

Arenario fontqueri-Armerietum marizii Aguiar, Penas \& Lousã 1998 corr. Aguiar, MonteiroHenriques \& Sánchez-Mata corr. hoc loco

HelianthemeteA (Br.-Bl. in Br.-Bl., Roussine \& Nègre 1952) Rivas Goday \& Rivas-Martínez 1963 em. Rivas-Martínez 1978

Trachynietalia distachyae Rivas-Martínez 1978

Trachynion distachyae Rivas-Martínez 1978

Euphorbietum acuminato-merinoi Aguiar \& Penas 2002

Isoeto-Nanojuncetea Br.-Bl. \& Tüxen ex Westhoff, Dijk \& Passchier 1946

Isoetalia Br.-Bl. 1936 em. Rivas Goday 1970

Cicendion (Rivas Goday in Rivas Goday \& Borja 1961) Br.-B1. 1967

Jonopsidio abulensis-Sedetum maireani Aguiar, Monteiro-Henriques \& Sánchez-Mata ass. nova

\section{REFERENCES}

Aguiar, C. - 2002- Flora e Vegetação da Serra de Nogueira e do Parque Natural de Montesinho - Mem. Doc. (ined.). Inst. Sup. Agron., Univ. Téc. Lisboa, Lisboa.

Aguiar, C., Monteiro-Henriques, T., Pereira Coutinho, X.\& Sánchez-Mata, D. - 2011a - Flora - In: Asensi, A. \& al. (Eds.). Flora and Vegetation of Iberian Ultramafics. Excursion Guide. Pp: 28-39. Inst. Politéc. Bragança. Univ. Coimbra.
Aguiar, C., Monteiro-Henriques, T. \& Sánchez-Mata, D. -2011b - Vegetation - In: Asensi, A. \& al. (Eds.). Flora and Vegetation of Iberian Ultramafics. Excursion Guide. Pp: 40-54. Inst. Politéc. Bragança. Univ. Coimbra.

Aguiar, C., Penas, A., Costa, J.C. \& Lousã, M. - 1998Vegetación endémica, no rupícola, de las rocas ultrabásicas de "Trás-os-Montes" (NE de Portugal) - Itinera Geobot. 11: 249-262. 
Aguiar, C., Capelo, J., Sequeira, M., Honrado, J. \& Mesquita, S. -2005- Floristical and Phytocenotical Diversity at the Climactical Dominion - 48th International Association for Vegetation Science Symposium. Marginal landscapes and nutrient-poor ecosystems - processes and adaptations. Lisboa.

Brady, K. U. B., Kruckeberg, A.R. \& Bradshaw Jr., H.D. 2005 - Evolutionary ecology of plant adaptation to serpentine soils - Annu. Rev. Ecol. Evol. Syst. 36: 243-66.

Cavazza, W., Roure, F., Spakman, W., Stampfli, G.M., Ziegler, P.A. \& TRANSMED Project Working Groups 2004- The TRANSMED Atlas: geological-geophysical fabric of the Mediterranean region - Final report of the project - Episodes 27(4): 244-254.

Clauzon, G., Suc, J.-P., Gautier, F., Berger, A . \& Loutre, M.F. - 1996- Alternate Interpretation of the Messinian Salinity Crisis: Controversy Resolved? - Geology 24(4): 363-366.

Emelyanov, E.M., Shimkus, K.M. \& Kuprin, P.N. - $2005-$ Explanatory Notes to the IBCM-SED Map Series Unconsolidated Sediments of the Mediterranean Sea (Scale 1:1,000,000) and the Black Sea (Scale 1:2,000,000) In: Hall, J.K., Krasheninnikov, V.A., Hirsch, F., Benjamini, C. \& Flexer A. (Eds.). Geological Framework of the Levant, Volume II: The Levantine Basin and Israel. Pp:155-186. Historical Productions-Hall Ltd. Jerusalem.

EuroGeoSurveys, The Geological Surveys of Europe 2010 - 1:5 Million International Geological Map of Europe and Adjacent Areas - www.bgr.de/karten/igme 5000/igme5000.htm.

García-Barriuso, M., Crespí, A.L., Nabais, C., Bernardos, S. \& Amich, F. - 2012- Mineral element composition in Antirrhinum subsection Streptosepalum (Plantaginaceae) in Western Europe (Iberian Peninsula) - Lazaroa 33: 19-26.

Gavilán, R.G., Vilches de la Serna, B. \& Fernández-González, F. - 2011 - Syntaxonomical review of Cytisetea scopario-striati communities in central Spain - Lazaroa 32: 29-72.

González, J.A., García-Barriuso, M., Ramírez-Rodríguez, R., Bernardos, S. \& Amich, F. - 2012- Plants used in folk cosmetics and hygiene in the Arribes del Duero Natural Park (western Spain) - Lazaroa 33: 9-18.

Iglesias, M.P.L., Ribeiro, M.L. \& Ribeiro, A. -1983- La interpretacion aloctonista de la estrutura del oroeste peninsular. Libro Jubilar J.M. Rios - Geologia de España 1: 459-467.

IUCN - 2001 - IUCN Red List Categories and Criteria: Version 3.1. - IUCN Species Survival Commission. IUCN. Gland, Switzerland and Cambridge. UK.

Kent, M. \& Coker, P. - 1992 - Vegetation Description and Analysis - J. Wiley \& Sons. Chichester.
Kruckberg, A.R. - 1986- An essay: The stimulus of unusual geologies for plant speciation - Syst. Bot. 11: 455463.

Kruckeberg, A.R. - 1992- Plant life of western North American ultramafics - In: Roberts, B. A. \& Proctor, J. (Eds.). The ecology of areas with serpentinized rocks - Kluwer Acad. Publ. Netherlands.

Kruckberg, A.R. - 2002 - Geology and Plant Life - University of Washington Press.

Lovett Doust, L. - 1981 - Population dynamics and local specialization in a clonal perennial (Ranunculus repens). I. The dynamics of ramets in contrasting habitats $-\mathrm{J}$. Ecol. 69: 743-755.

Mac Arthur, R.H. \& Wilson, E.O. - 1967 - The Theory of Island Biogeography - Princeton Univ. Press. Princeton.

Monteiro-Henriques, T. - 2010 - Landscape and phytosociology of the Paiva River's hydrographical basin Mem. Doc. (ined.). Inst. Sup. Agron., Univ. Téc. Lisboa, Lisboa. home.isa.utl.pt/ tmh/

Monteiro-Henriques, T. \& Aguiar, C. - 2011 - Bioclimatology, biogeography and land use of Trás-os-Montes In: Asensi, A. \& al. (Eds.). Flora and Vegetation of Iberian Ultramafics. Excursion Guide. Pp. 13-18. Inst. Politéc. Bragança. Univ. Coimbra.

Pinto da Silva, A.R. - 1970- A flora e a vegetação das áreas ultrabásicas do nordeste transmontano - Agron. Lusit. 30: 175-364.

Pinto-Gomes, C., Paiva-Ferreira, R. \& Meireles, C. 2010 - New Proposals on Portuguese Vegetation (II) Lazaroa 31: 59-65.

Ribeiro, S., Gonçalves, P.\& Espírito-Santo, M.D. -2012Land-use influence on Mediterranean perennial swards of Poa bulbosa: a case study in the International Tagus Region - Lazaroa 33: 51-64.

Rivas-Martínez, S. -2004- Mapas bioclimáticos y biogeográficos. www.ucm.es/info/cif/form/maps.htm.

Rivas-Martínez, S. -2005- Notions on dynamic-catenal phytosociology as a basis of landscape science - Plant Biosyst. 139(2):135-144.

Rivas-Martínez, S., Rivas Sáenz, S. \& Penas, A. -2011Worldwide bioclimatic classification system. Global Geobot. 1(1): 1-638.

Sequeira, E.M., \& Pinto da Silva, A.R. - 1992- Ecology of serpentinized areas of North-East Portugal - In: Roberts, B. A. \& Proctor, J. (Eds.). The ecology of areas with serpentinized roks. A world view. Pp. 169-197. Kluwer Academic Publishers. Netherlands.

Sequeira, E., Aguiar, C. \& Meireles, C. -2010 - Ultramafics of Bragança Massif: soils, flora and vegetation In: Evelpidou, N., de Figueiredo, T., Mauro, F., Vahap, A. \& Vassilopoulos, A. (Eds.). Natural Heritage from East to West. Pp. 143-149. Springer Verlag. Berlin. 